\section{SOI: $1.1 /$ TAS DOI: $10.15863 / \mathrm{TAS}$ International Scientific Journal Theoretical \& Applied Science}

p-ISSN: 2308-4944 (print) e-ISSN: 2409-0085 (online)

Year: $2018 \quad$ Issue: 02 Volume: 58

Published: $28.02 .2018 \quad$ http://T-Science.org

SECTION 20. Medicine.
Rehana Bibi

PMDC: 83720-P

Doctor in Bahawal victoria Hospital Bahawalpur,

Pakistan.

rehanahanif07@gmail.com

Misbah Akbar

PMDC: 81982-P

Doctor in Jinnah Hospital Lahore, Pakistan Mibiyaakbar12@gmail.com

Qurat-ul-Ain Maqbool PMDC: 83188-P

Doctor in Bahawal victoria Hospital Bahawalpur,

Pakistan.

Quratulainmaqbool4@gmail.com

\title{
RETINOPATHY IN DIABETIC PATIENTS
}

\begin{abstract}
AIMS AND OBJECTIVES: The objective of this study was to determine incidence of retinopathy in diabetic patients so that early management should be done to minimize this complication of diabetes mellitus.

MATERIALS AND METHODS: In this study 140 diabetic patients were included of either gender having ages of 20-80 years reported in Medical Unit of Bahawal victoria Hospital Bahawalpur, Pakistan from 1st June 2015 to 31th May 2016. Tables and charts used to express percentages, standard deviation and means.

RESULTS: One hundred and forty patients were studied. Out of them 40 were taking insulin therapy and 100 patients were taking oral hypoglycemic. Fifty patients had Diabetic retinopathy with incidence of 35.7\%. Among these 50 patients, 45 were having background retinopathy and 5 had proliferative retinopathy including 35(70\%) males and 15(30\%) females. The incidence of disease was higher in patients with 55 years of age or above with diabetes of duration of 15 years or more.

CONCLUSION: It was concluded from this study that incidence of retinopathy in diabetic patients is very high in our population and it increases with duration of disease. Its incidence is more in patients having IDDM than NIDDM of either gender and of any age group

Key words: incidence, retinopathy, Diabetic patients

Language: English

Citation: Bibi R, Akbar M, Maqbool Q (2018) RETINOPATHY IN DIABETIC PATIENTS. ISJ Theoretical \& Applied Science, 02 (58): 177-180.

Soi: http://s-o-i.org/1.1/TAS-02-58-37 Doi: crossef https://dx.doi.org/10.15863/TAS.2018.02.58.37
\end{abstract}

\section{INTRODUCTION}

$\mathrm{DM}$ is a disease in which there is increases blood sugar level and abnormal carbohydrate, protein and fat metabolism linked with insulin deficiency either absolute or relative deficiency. It is one of the most common endocrinal disorder causing high morbidity and mortality. About $25 \%$ of diabetic patients have IDDM and $75 \%$ have NIDDM. DM occurs in either sexes males or females in any every group. It affects all organ systems in the body and causes many complications. Its main complications are macro and micro-vascular diseases. These vascular diseases include coronary artery disease, peripheral arterial disease, CVA, retinopathy and diabetic nephropathy. DM causes pathology of eyes in many ways. Most common eye pathology is diabetic retinopathy. It is very common cause of blindness in USA. ${ }^{1}$ Diabetic patients are 20 times more susceptible to blindness than non diabetic patients. Incidence of blindness in diabetic patients is
$2 \% .^{2}$ Retinopathy in diabetics has different incidence in different age groups. It also depends on duration of disease. About 10-20\% of simple retinopathy converts to proliferative retinopathy after 10 years of disease and $50 \%$ of them develop blindness after 5 years of age. Incidence of retinopathy is higher in IDDM than NIDDM. So proliferative retinopathy more common in patients with IDDM and causes blindness in people with 20-65 years age. ${ }^{3}$ Despite many measures taken to control complications in diabetic patients still blindness is very common due to diabetic retinopathy. ${ }^{4}$ Aim of this study was to determine incidence of diabetic retinopathy in patients reported in medical out patient doors or admitted in the medical unit.

\section{MATERIALS AND METHODS}

This research was done in Medical unit of Bahawal Victoria Hospital Bahawalpur. There were 140 patients having diabetes having varying age 


\begin{tabular}{|c|c|c|c|c|c|c|}
\hline Impact Factor: & $\begin{array}{l}\text { ISRA (India) } \\
\text { ISI (Dubai, UAE } \\
\text { GIF (Australia) } \\
\text { JIF }\end{array}$ & $\begin{array}{r}=1.344 \\
=0.829 \\
=0.564 \\
=1.500\end{array}$ & $\begin{array}{l}\text { SIS (USA) } \\
\text { PИНЦ (Russia) } \\
\text { ESJI (KZ) } \\
\text { SJIF (Morocco) }\end{array}$ & $\begin{array}{l}=0.912 \\
=0.207 \\
=4.102 \\
=\mathbf{2 . 0 3 1}\end{array}$ & $\begin{array}{l}\text { ICV (Poland) } \\
\text { PIF (India) } \\
\text { IBI (India) }\end{array}$ & $\begin{array}{l}=6.630 \\
=1.940 \\
=4.260\end{array}$ \\
\hline
\end{tabular}

groups, duration of illness, gender and different therapies.

There were three steps in this study

1 History taking from all the cases

2 Examination of eyes done of all the cases

3 Previous records of patients seen for any record of retinopathy

Retinopathy was diagnosed on the basis of given criteria
A- Background retinopathy
1 Closure and dilatation of capillaries
2 Micro-aneurysms
3 Soft or cotton wool exudates
4 Arteriovenous nipping
5 Hard exudates
B- Proliferative diabetic retinopathy
1 formation of new vessels
2 Detachment of retina
3 Hemorrhage of vitreous humor
4 Presence of scarring studied.

Other risk factors of retinopathy were not

\section{RESULTS}

The 140 cases having age between 20-80 years were selected for the study. Most of the patients were between the age group of 40-60 years. In 140 cases 80 were males and 60 were females. They were either on insulin or oral hypoglycemic. The duration of disease was 6 months to 20 years. In 140 cases 50 had diabetic retinopathy most of them among 40-60 years of age. Forty five patients were having background retinopathy and 5 cases had proliferative retinopathy. Among them 35(70\%) were males and $15(30 \%)$ were females. In age group 20-30 years 4 out of 18 had retinopathy. There were 25 cases between 31-40 years of age and 10 out of them had retinopathy. Eight patients out of 25 cases having age 41-50 years had retinopathy. Sixteen cases of retinopathy found out of 40 cases among 51-60 years of age. Among 61-70 years of age 8 out of 12 cases were having retinopathy. In 71-80 years age group, 4 out of 20 cases had retinopathy (Table-1). If we talk about duration of disease then 10 cases out of 60 patients had retinopathy with duration of disease 1-5 years. There were 25 cases with duration of disease 6-10 years and 5 of them had retinopathy. Thirty cases had duration of disease 11-15 years and 20 of them had retinopathy. In 16 years or above duration of disease 15 out of 25 had retinopathy. In 140 cases 40 were on insulin and $15(37.5 \%)$ of them had retinopathy (Table-2). Among them 100 were on oral hypoglycemic agents and $35(35 \%)$ of them had retinopathy (Table-3). In 140 cases 55 were on regular therapy of diabetes and $20(36.3 \%)$ had retinopathy. Among them 85 were on irregular therapy and $30(35.2 \%)$ of them had retinopathy (Table-4).

Different age groups and diabetic retinopathy

Table-I.

\begin{tabular}{|c|c|c|}
\hline Age (yrs) & No. of Pts & Pts with Retinopathy (\%) \\
\hline $20-30$ & 18 & $4(22.2 \%)$ \\
\hline $31-40$ & 25 & $10(40 \%)$ \\
\hline $41-50$ & 25 & $8(32 \%)$ \\
\hline $51-60$ & 40 & $16(40 \%)$ \\
\hline $61-70$ & 12 & $8(66.6 \%)$ \\
\hline $71-80$ & 20 & $4(20 \%)$ \\
\hline Total & 140 & 50 \\
\hline
\end{tabular}

Table-II.

Disease-duration and retinopathy in patients

\begin{tabular}{|c|c|c|}
\hline Duration of disease(years) & No. of Pts & Pts having retinopathy \\
\hline $1-5$ & 60 & $10(16.6 \%)$ \\
\hline
\end{tabular}




\begin{tabular}{l|lr|ll|ll} 
& ISRA (India) & $=\mathbf{1 . 3 4 4}$ & SIS (USA) & $=\mathbf{0 . 9 1 2}$ & ICV (Poland) & $=\mathbf{6 . 6 3 0}$ \\
Impact Factor: & ISI (Dubai, UAE) & $=\mathbf{0 . 8 2 9}$ & PUHЦ (Russia) & $=\mathbf{0 . 2 0 7}$ & PIF (India) & $=\mathbf{1 . 9 4 0}$ \\
& GIIF (Australia) & $=\mathbf{0 . 5 6 4}$ & ESJI (KZ) & $=4.102$ & IBI (India) & $=\mathbf{4 . 2 6 0}$ \\
& JIF & $=\mathbf{1 . 5 0 0}$ & SJIF (Morocco) & $=\mathbf{2 . 0 3 1}$ & & \\
\hline
\end{tabular}

\begin{tabular}{|c|c|c|}
$6-10$ & 25 & $5(20 \%)$ \\
\hline $11-15$ & 30 & $20(66.6 \%)$ \\
\hline $16 \&$ above & 25 & $15(60 \%)$ \\
\hline Total & 140 & 50 \\
\hline
\end{tabular}

Table-III.

Retinopathy in patients on insulin therapy or taking oral anti diabetic drugs

\begin{tabular}{|l|c|c|}
\hline \multicolumn{1}{|c|}{ Drug used } & No. of Pts & Patient with retinopathy \\
\hline Insulin & 40 & $15(37.5 \%)$ \\
\hline Oral hypo-glycaemic & 100 & $35(35 \%)$ \\
\hline Total & 140 & 50 \\
\hline
\end{tabular}

Retinopathy in patients taking regularly antidiabetic drugs and those taking drugs Irregularly

\begin{tabular}{|l|c|c|}
\hline \multicolumn{1}{|c|}{ Drug Taking } & No. of Pts & Pts with retinopathy (\%) \\
\cline { 1 - 3 } Regular & 55 & $20(36.3 \%)$ \\
\hline Irregular & 85 & $30(35.2 \%)$ \\
\hline Total & 140 & 50 \\
\hline
\end{tabular}

\section{DISCUSSION}

There is lack of proper information about diabetes and its complications in Pakistan. Main cause of this poor education is lack of facilitis, lack of awareness in community, patients and health workers.There is not proper resource of information and decreased man power. Most common cause of blindness in USA is retinopathy due to diabetes. ${ }^{1}$ It is also a major cause of blindness in pakistan. According to a study done in Pakistan in 1981 the prevalence of retinopathy was $2.4 \%$ in 1447400 people. $^{5}$ There is different prevalence of diabetic retinopathy in different countries. In a study done in Joslin clinic ${ }^{6}$, there was $25 \%$ incidence of retinopathy due to DM, 7\% incidence in those having from less than 10 years, $26 \%$ in those having DM from 10-14 years and 63\% in those having DM from more than 15 years. According to another study done in Karachi by Dr. Akhtar the incidence of retinopathy was 26\%.7 In another study done in Lahore in 1986 the incidence of diabetic retinopathy was $60 \%{ }^{8}$ The prevalence of diabetic retinopathy range from 24$70 \%$ in Australia ${ }^{9}$, in denmark ${ }^{10}$, in Ireland ${ }^{11}$ and USA. ${ }^{12}$ according to our study incidence of diabetic retinopathy is $35.7 \%$. our result is similar to other studies done in Pakistan and other countries. Its incidence depends on age of the patient and duration of disease. Maximum incidence of $85 \%$ occurs in the patients having age between 30-60 years having duration of disease 15 years or more. These results are same as in other studies done in different countries. Patients having IDDM have higher incidence of retinopathy than $\operatorname{NIDDM}(37.5 \%$ and $35 \%$ respectively).patients taking regular treatment had incidence of $36.3 \%$ than those taking irregular treatment $35.2 \%$. These figures are comparable to the results of studies done by Pirat ${ }^{13}$ and DCCT. ${ }^{14}$ Incidence of diabetic retinopathy is relatively lower in those patients taking insuline therapy regularly as compared to those taking oral anti-diabetics irregularly. So compliance with therapy is very important ti avoid complications of diabetes. Most common complication of diabetes is retinopathy which is associated with non compliance of treatment and long duration of disease. Results of our study are similar to other studies done before in Pakistan and in other countries of world. Patients of age more than 50 years of age have higher incidence of retinopathy. 


\begin{tabular}{|c|c|c|c|c|c|c|}
\hline Impact Factor: & $\begin{array}{l}\text { ISRA (India) } \\
\text { ISI (Dubai, UAE } \\
\text { GIF (Australia) } \\
\text { JIF }\end{array}$ & $\begin{array}{l}=1.344 \\
=0.829 \\
=0.564 \\
=1.500\end{array}$ & $\begin{array}{l}\text { SIS (USA) } \\
\text { PИНЦ (Russia } \\
\text { ESJI (KZ) } \\
\text { SJIF (Morocco }\end{array}$ & $\begin{array}{l}=0.912 \\
=0.207 \\
=4.102 \\
=2.031\end{array}$ & $\begin{array}{l}\text { ICV (Poland) } \\
\text { PIF (India) } \\
\text { IBI (India) }\end{array}$ & $\begin{array}{l}=6.630 \\
=1.940 \\
=4.260\end{array}$ \\
\hline
\end{tabular}

\section{CONCLUSION}

Our community has high number of diabetic patients with retinopathy.It is more in patients having IDDM than NIDDM. Both males and females and all age groups are equally susceptible to diabetic
retinopathy.Duration of disease is directly proportional to the incidence of diabetic retinopathy. More duration of disease more incidence of retinopathy.

\section{References:}

1. Khan HA, Moorhead HB (1993) Statistics on blindness in the model reporting area, 1969-70, Publication No. 72-427. Washington DC, National Institute of Health, 1993.

2. Blakenship GW (1981) Diabetic retinopathy present and future, Ophthalmol 88,658:1981.

3. Jhon Shilling (1994) Retinal vascular diseases; Kanski Clinical Ophthalmology(eds) 3,344-78; 1994.

4. Dodson PM (1997) Birmingham Heartland Hospital, Screening for retinopathy, DIABETES(Reviews International) Vol. 6, No. 1: 1-2 January 1997.

5. Jhons AW (1988) Role of international nongovernment organizations and eye health in developing countries. Pak J Ophthalmol, 4: 123, 1988.

6. Khan HA, Bradley RF (1975) Prevalence of diabetic retinopathy: Age, sex and duration of diabetes. Br J Ophthalmol, 59: 345, 1975.

7. Akhtar Jamal (1990) Age ,sex and duration relationship and prevalence of retinopathy in Pakistani population. Pak J Ophthalmol, 6: 6-8, 1990.

8. Jahangir S (1989) Diabetic retinopathy in Pakistani diabetics. Pak J Ophthalmol, 5:77, 1989.

9. Mitchell P (1980) The prevalence of diabetic retinopathy. A study of 1300 diabetics from
Newcastle and Hunter valley. Aust J Ophthalmol, 8: 241, 1980.

10. Nielson NV (1984) Diabetic retinopathy. The course of retinopathy in insulin treated diabetics. A one year epidemiological cohort study of diabetes mellitus. The Island of Falster, Denmark. Acta Ophthalmol, 62: 256, 1984.

11. Danielson R, Jonason F and Helgason T (1982) Prevalence of retinopathy and proteinuria in type I diabetes in Iceland. Acta Med Scand 212, 1982.

12. Klien R, Davis MD, Mosws SE, Klien B and DeMets DL (1985) The Wisconsin Epidemiologic Study of Diabetic Retinopathy. A comparison of retinopathy in younger and older onset diabetic person. In Vranic $M$, Hollenberg $\mathrm{CH}$ and Stiener $\mathrm{G}$ (eds): Comparison of Type I and Type II Diabetes. New Yark, Plenum Press, pp 321-35, 1985.

13. Pirat J (1978) Diabetes mellitus and its degenerative complications: A prospective study of 4400 patients observed between 1947 and 1973. Diabetic Care 1978: 1: 168-88, 25263.

14. (1993) DCCT Research Group. The effect of intensive treatment of diabetes on the development and progression of long term complications in insulin-dependent diabetes mellitus. N Eng J Med. 1993; 329: 977-86. 